\title{
Composition and Specification of the Blended Fuels Aqueous Ethanol-Biodiesel and Aqueous Ethanol-Diesel-Biodiesel Prepared by Sub Critical
}

\author{
Hanny F. Sangian ${ }^{1 *}$, Ramli Thahir², Tun Sriana ${ }^{3}$, Zami Furqon $^{3}$, Silvya Y. Agnesty ${ }^{3}$ \\ ${ }^{1}$ Department of Physics, Sam Ratulangi University, 95115 Manado, Indonesia. \\ ${ }^{2}$ Department of Chemical Engineering, Politeknik Negeri Samarinda, 75136 Samarinda, Indonesia. \\ ${ }^{3}$ Department of Oil and Gas Processing Engineering, Polytechnic of Energy and Minerals, 58315 Cepu Blora, Indonesia.
}

ORCID: 0000-0003-1474-9701 (Hanny Sangian)

\begin{abstract}
The biodiesel blended with aqueous ethanol and diesel was successfully prepared to employ a near isochoric subcritical in which methyl esters were derived from coconut oils. Procedures are as follows: Fermentation of Arenga pinnata sap, a distillation of ethanol using a reflux column, preparation of biodiesel, characterization of biodiesel by GC/MS, blending of aqueous ethanol-biodiesel and aqueous ethanol-dieselbiodiesel, measurement of composition, and analysis of fuel parameters with ASTM standard. The maximum yields of biodiesel obtained were $98.82 \%(\mathrm{v} / \mathrm{v})$ and $96.67 \%(\mathrm{w} / \mathrm{w})$. The coconut oil methyl esters (COME) degraded from triglycerides were dominated by the short carbon chains, such as $\mathrm{C}_{9} \mathrm{H}_{18} \mathrm{O}_{2}$, $\mathrm{C}_{11} \mathrm{H}_{22} \mathrm{O}_{2}, \mathrm{C}_{13} \mathrm{H}_{26} \mathrm{O}_{2}, \mathrm{C}_{15} \mathrm{H}_{30} \mathrm{O}_{2}$, and $\mathrm{C}_{17} \mathrm{H}_{34} \mathrm{O}_{2}$. It was found that the aqueous ethanol-biodiesel and aqueous ethanol-biodieseldiesel formed an equilibrium line in a triangular graph in specific compositions. The aqueous ethanol concentrations using in the present work were 94-97\%. Components pure ethanol-biodiesel-water, which were in the stable blends, had a range of $13.16-33.95,65.00-86.00$, and $0.84-1.05 \%$. Meanwhile, the blends aqueous ethanol-diesel-biodiesel were $7.45-21.88,10.64-25.97$, and $56.25-81.91 \%$, respectively. It was discovered that droplets appeared in solution when using ethanol with purity below $95 \%$ but were distributed uniformly. The addition of biodiesel continually after a stable emulsion formed, the phase separation would not have occurred.
\end{abstract}

Keywords: Biodiesel, Blending, Droplet, Emulsion, Methyl Ester, Subcritical

\section{INTRODUCTION}

Developing countries, including Indonesia, are facing an energy shortage since the petroleum reserves are diminishing fast [1]. The electricity energy need is mostly supplied by power plants using coal, which results in a considerable pollutant. To overcome the pollution emitted by cars and industrial sectors and the lack of fossil-based fuels is necessary and urgent to find the renewable energy derived from bioresources [2-5].

The Indonesian scientists are thinking and working hard to address the lack of energy and to invent new sources to substitute a part of petroleum fuels. The production of bioethanol, biodiesel, and biogas and hydrogen is most probable to counterbalance the decrease of fossil fuel reserves and the increase of the energy demand. The works have been conducted and developed as follows: Bioethanol and hydrogen generally are synthesized from sugar, starch, and lignocellulose [6].

The technology used for bioethanol production derived from sugar and starch is relatively well-established. Meanwhile, lignocellulose is still challenged [7-8]. Indonesia is very successful in developing and applying the blended fuel of diesel and biodiesel. The biodiesel blended $30 \%$ has been mandatory in industrial sectors, including transportation, and according to government regulation expected, it would be increased to $40 \%$ in 2020 .

Research affords in Indonesia and Malaysia are developing the palm oil becoming methyl esters blended with diesel. Since the palm oils are oversupplied and cheap, they are feasible to produce massively.

Many investigations have been reported relating to the preparation and application of biodiesel, or palm oil methyl esters, abbreviated as POME, and the technology is relatively well-mature [9]. The state of POME technology is just decreasing the production cost [10]. The most challenging now is that POME is edible oils competing with food purposes [1112]. Other works are expanding to the non-edible oils to the raw materials that are diverse [13].

The works of the blended fuels involving biodiesel-ethanol and biodiesel-diesel-ethanol have been done for years as reviewed previously [14]. The study found that the physical- and chemical properties and emission of the fuels were slightly different from diesel fuel. The other work through a review study showed that diesel blended with ethanol, or biodiesel gave positive- and negative impact on the engine [15].

Investigators discovered that NOx emission increased, and the duration of filter replacement declined. The significant results using those fuels were the decrease of sulfuric based emission and the incline of the utilization of the biofuel.

The engine testing of different composition of diesel, ethanol/methanol, or biodiesel was compared with diesel. The 
results obtained showed that fuel consumption increased compared to that of diesel fuel. The emission of $\mathrm{CO}$ and $\mathrm{HC}$ inclined, but NO declined, as shown in a previous investigation [16].

Intensive references survey which had been conducted obtained that emulsion fuels involving ethanol, biodiesel, and diesel generally used absolute alcohol, which was still expensive. On the other hand, the aqueous ethanol is possible to blend with biodiesel and diesel, becoming a stable emulsion. The diesel/biodiesel from COME, which was prepared by the subcritical method and blended with aqueous ethanol, has not been developed either investigated the fuel parameters.

This article is aimed at reporting of the emulsified fuel of aqueous ethanol-biodiesel and aqueous ethanol-dieselbiodiesel employing a near isochoric subcritical method in which methyl esters were converted from coconut oil.

The steps of work are as follows: Preparation of coconut methyl esters using a near isochoric trans-esterification; fermentation of arenga pinnata sap; a distillation of ethanol employing a reflux separator; the blending of aqueous ethanol-biodiesel and aqueous ethanol-diesel-biodiesel forming a stable emulsion.

Measurement of fuel parameters density, Specific gravity (SG), American Petroleum Institute gravity (API), viscosity, flash point, cetane number $(\mathrm{CN})$, pour point, and distillation property, were conducted. All fuel parameters were measured following a standard of American Society for Testing and Materials (ASTM).

\section{EXPERIMENTAL SECTION}

\section{Chemicals}

The coconut oil was purchased from a home industry located in Minahasa, North Sulawesi, Indonesia. Methanol used the industry-grade sold commercially, and the ethanol $94-96 \%$ was extracted from arenga pinnata liquor employing reflux distillation. In comparison, $97 \%$ was produced from purifying aqueous ethanol using an activated lime particle.

\section{Instrumentation}

A home-made reflux column and reactor were used with a specification as follows: reactor capacity $600 \mathrm{~mL}$; a column tube 2 inches; a thermometer (56-238; Sellery; Singapore) and pressure gauge (56-374; Sellery; Singapore). The methyl esters were characterized an instrument with a model GCMS-2010 QP; Shimadzu; Japan located at Central Lab, Malang State University, East Java Indonesia, and it was operated at a moderate pressure 5 bar.

The tools which follow the standard issued by the American Society for Testing and Materials (ASTM) and were based at Oil and Gas Engineering Laboratory, Polytechnic of Energy and Mineral, Cepu Blora Central Java, and at Samarinda State Polytechnic, East Kalimantan Indonesia, were employed.

The parameters, instrument specifications, and ASTM codes are following: the density $\left(15^{\circ} \mathrm{C}\right.$; D4052; Koehler; New York
USA); viscosity $\left(40^{\circ} \mathrm{C}\right.$; D445; KV1000; Kohler; New York USA); ASTM color (D1599; K13200 Petroleum Colorimeter; Koehler; New York USA), flash point PMCC (D93; Electric Pensky - Martens; SDM Torino, Italy), Reid vapor pressure (D323; Koehler; New York USA), pour point (D97; Lawler Manufacturing Company; Indianapolis USA), and distillation (D86; Koehler; New York USA).

\section{Procedures}

The reactant's coconut oil and methanol with ratio 10.75:2.52 $(\mathrm{v} / \mathrm{v})$ were mixed with $0.01 \mathrm{~g}$ catalyst $\mathrm{KOH}$, and then the mixture was stirred for $1-5 \mathrm{~min}$. The solution, which was volume $575 \mathrm{~mL}, 0.96 \mathrm{~V}$ (V reactor volume), was poured into the reactor. The reactor was locked tightly, and then the gas stove turned on after the weight was measured. The initial reactor temperature, room temperature, and pressure were measured and noted on the logbook.

While the heat entered the reactor from gas burning, the pressure and temperature increased gradually. Since the reactor was not equipped by magnetic stirring, the reactor was shaken periodically, aiming to improve the collision between reactants. The temperature rose from $30-150{ }^{\circ} \mathrm{C}$, meanwhile the gauge pressure needle moved from 1 - 15 bar, which took for one hour. The pressure stroke in which the pressure increased remarkably occurred at 15 bar. After the stroke point passed, the pressure increased to 40 bars only for $3-5 \mathrm{~min}$. The present experiment was just limited at maximum pressure 15 bar because of safety reasons. The mixture volume at $550 \mathrm{~mL}$ $(0.92 \mathrm{~V})$ was conducted with a similar step, as described previously.

When the chemical reaction finished, the products were cooled down for hours and then separated. The wash step was carried out after separation, which aimed to eliminate catalyst and $\mathrm{KOH}$, and after heating, the COME was stored and isolated inside a bottle. The GC/MS was employed for methyl esters identification.

The blending of aqueous ethanol-biodiesel and aqueous ethanol-diesel-biodiesel were done simply. Firstly, the seven milliliters aqueous ethanol was poured into a flask $100 \mathrm{~mL}$, and then COME was added gradually with aqueous ethanol while shaken gently. When COME was dissolved completely, the stable emulsion of aqueous ethanol-biodiesel was attained.

The composition of the pure ethanol-COME-water was defined as $\mathrm{V}_{\mathrm{Et}}: \mathrm{V}_{\mathrm{COME}}: \mathrm{V}_{\text {Water }}$ in which $\mathrm{V}_{\text {et }}$ was obtained from $\%$ of ethanol times volume of aqueous ethanol. At the same time, $V_{\text {Water }}$ was the difference in the volume of aqueous- and pure ethanol.

The blending process of aqueous ethanol-diesel-biodiesel was relatively similar to the previous procedure. The second blending was only added to the third component (diesel) in the mixture. In the first step, aqueous ethanol was mixed with diesel in many ratios of which were separated into two phases firstly. The biodiesel was poured gradually into the mixture while shaken slowly until three components were mixed completely. The compositions consisted of volume and percentage $(\% \mathrm{v} / \mathrm{v})$. 
The triangular analysis was adapted the template which was available online on a web http://www.phasediagram.dk/download/TriangularExcelTemp late.htm. The proportions of the three components, the pure ethanol, biodiesel, and water, and aqueous ethanol, diesel, and biodiesel, were moved in the template and studied. The final work was the measurement and analysis of fuel parameters whereby the procedure was adapted from authors and the instrument guidelines [17]. The measurement and analysis of fuel parameters, as mentioned in the introduction section. To analyze the distillation behavior as heated followed and was adapted from the work reported by authors [18].

\section{RESULT AND DISCUSSION}

\section{Yield and GC/MS Analysis}

The mass and volume of the products obtained were measured for yield calculation. The four types of yield following are: the first yield assigned as yield ${ }_{1}$ is formulated as the ratio of the weight of COME and coconut oil, while yield ${ }_{2}$ is defined as the weight of COME and coconut oil + methanol. The yield 3 is based on a formula of volume of COME per coconut oil. Meanwhile, yield 4 is the volume ratio of COME/coconut oil + methanol, respectively, as presented in Table 1.

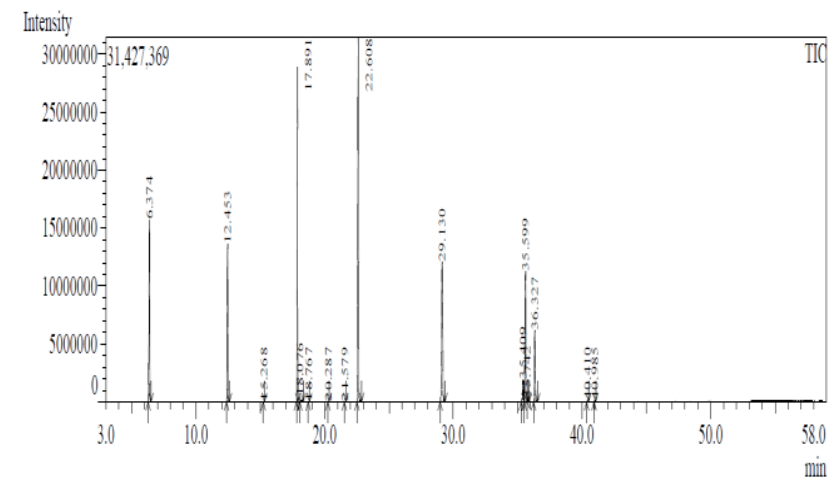

(A)

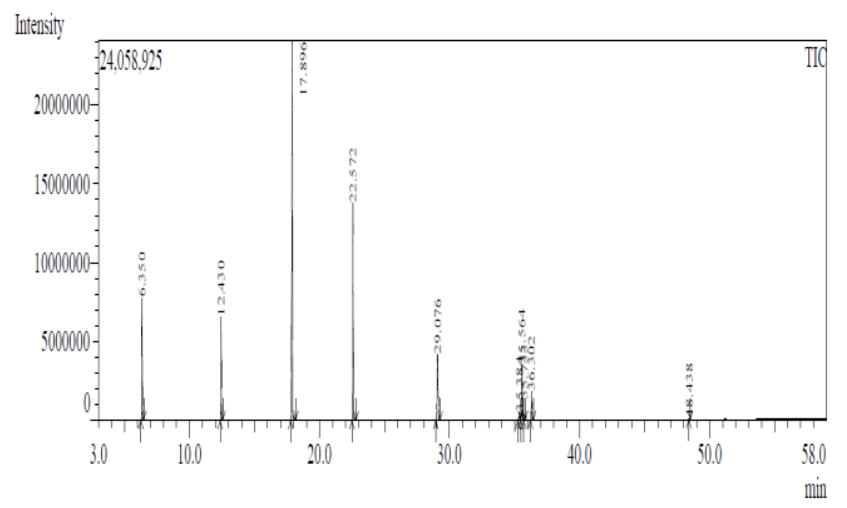

(B)

Figure 1. The GC/MS spectra of COME vs retention time (RT) conducted by employing the near isochoric subcritical method $\mathrm{P}=15$ bar; $575 \mathrm{~mL}(\mathrm{~A})$ and $\mathrm{P}=7 \mathrm{bar} ; 550 \mathrm{~mL}(\mathrm{~B})$ for $1 \mathrm{~h} ; \mathrm{T}=30$ $150{ }^{\circ} \mathrm{C}$
Two parameters 15 bar $(575 \mathrm{~mL})$ and 7 bar $(550 \mathrm{~mL})$ were employed on the experiment. It was found that two parameters resulted in a relatively high yield recorded at $98.92 \%(\mathrm{v} / \mathrm{v})$, which was comparable with previous work [19]. But the data showed that the change of pressure and mixture volume slightly affected the yield. The methyl esters formed from transesterification using a near isochoric subcritical method (P 15 bar; V $575 \mathrm{~mL}$ and $\mathrm{P} 7 \mathrm{bar}$; V $550 \mathrm{~mL}$ for $1 \mathrm{~h}$ ) are shown in GC/MS spectra as presented in Figure 1A and 1B.

The data show that the yield obtained are relatively similar when employing parameters, I and II. Compared to the atmospheric trans-esterification, the subcritical method was conducted just taking 1 hour after the stove was turned on.

Table 1. The yield of COME resulted assigned by yield ${ }_{1}$, yield 2 yield $_{3}$, and yield ${ }_{4}$ conducted at $15(575 \mathrm{~mL})$ and 7 bar $(550 \mathrm{~mL})$ for $1 \mathrm{~h} ; 150^{\circ} \mathrm{C}$

\begin{tabular}{|l|c|c|c|c|}
\hline Name of sample & $\begin{array}{c}\text { Yield }_{\mathbf{1}} \\
(\boldsymbol{\%} \mathbf{w} / \mathbf{w})\end{array}$ & $\begin{array}{c}\text { Yield }_{\mathbf{2}} \\
(\boldsymbol{\%} \mathbf{w} / \mathbf{w})\end{array}$ & $\begin{array}{c}\text { Yield }_{3} \\
(\boldsymbol{\%} \mathbf{v} / \mathbf{v})\end{array}$ & $\begin{array}{c}\text { Yield } \\
(\boldsymbol{\%} \mathbf{4} / \mathbf{v})\end{array}$ \\
\hline $\begin{array}{l}\text { COME } \\
(575 \mathrm{ml} ; 15 \text { bar })\end{array}$ & 93.84 & 78.39 & 98.82 & 80.06 \\
\hline $\begin{array}{l}\text { COME } \\
(550 \mathrm{~mL} ; 7 \text { bar })\end{array}$ & 96.67 & 81.06 & 98.82 & 79.99 \\
\hline
\end{tabular}

Two figures show that the peaks displaying are relatively symmetry and similar, which means the change of pressure and volume do not significantly affect the methyl esters degraded from triglycerides.

Table 2. The coconut methyl ester (COME) and retention time (RT) using at the near isochoric subcritical esterification (V 575 $\mathrm{mL} ; \mathrm{P}_{\max }=15$ bar; $\mathrm{t}=1 \mathrm{~h} ; \mathrm{T}=30-150{ }^{\circ} \mathrm{C}$; ratio (in $\mathrm{V}$ ) coconut oil to methanol $=465.45: 109.11 ;$ mass of $\mathrm{KOH}=5 \mathrm{~g}$

\begin{tabular}{|l|l|l|l|l|}
\hline $\begin{array}{l}\text { RT } \\
(\mathbf{m i n})\end{array}$ & Compound & Formula & $\begin{array}{l}\text { Area } \\
(\%)\end{array}$ & $\begin{array}{l}\text { Height } \\
(\%)\end{array}$ \\
\hline 6.37 & Octanoic Acid & $\mathrm{C}_{9} \mathrm{H}_{18} \mathrm{O}_{2}$ & 12.17 & 12.90 \\
\hline 12.45 & Decanoic Acid & $\mathrm{C}_{11} \mathrm{H}_{22} \mathrm{O}_{2}$ & 9.28 & 11.15 \\
\hline 15.27 & Undecanoic Acid & $\mathrm{C}_{12} \mathrm{H}_{24} \mathrm{O}_{2}$ & 0.02 & 0.03 \\
\hline 17.89 & Dodecanoic Acid & $\mathrm{C}_{13} \mathrm{H}_{26} \mathrm{O}_{2}$ & 15.74 & 23.75 \\
\hline 18.08 & - & - & 0.39 & 0.35 \\
\hline 18.77 & Dodecanoic Acid & $\mathrm{C}_{12} \mathrm{H}_{24} \mathrm{O}_{2}$ & 0.02 & 0.03 \\
\hline 20.29 & Heptadecanoic Acid & $\mathrm{C}_{18} \mathrm{H}_{36} \mathrm{O}_{2}$ & 0.03 & 0.05 \\
\hline 21.58 & Octanoic Acid & $\mathrm{C}_{13} \mathrm{H}_{26} \mathrm{O}_{2}$ & 0.03 & 0.04 \\
\hline 22.61 & Tetradecanoic Acid & $\mathrm{C}_{15} \mathrm{H}_{30} \mathrm{O}_{2}$ & 27.10 & 25.84 \\
\hline 29.13 & Hexadecanoic Acid & $\mathrm{C}_{17} \mathrm{H}_{34} \mathrm{O}_{2}$ & 16.27 & 9.91 \\
\hline 35.41 & $9,12-$ Octadecadienoic & $\mathrm{C}_{19} \mathrm{H}_{34} \mathrm{O}_{2}$ & 2.00 & 1.57 \\
\hline 35.60 & 9-Octadecenoic Acid & $\mathrm{C}_{19} \mathrm{H}_{36} \mathrm{O}_{2}$ & 11.36 & 9.22 \\
\hline 35.74 & 9-Octadecenoic Acid & $\mathrm{C}_{19} \mathrm{H}_{36} \mathrm{O}_{2}$ & 0.01 & 0.03 \\
\hline 36.33 & Octadecanoic Acid & $\mathrm{C}_{19} \mathrm{H}_{38} \mathrm{O}_{2}$ & 5.47 & 5.03 \\
\hline 40.41 & - & - & 0.07 & 0.05 \\
\hline 40.99 & Eicosanoic Acid & $\mathrm{C}_{21} \mathrm{H}_{42} \mathrm{O}_{2}$ & 0.05 & 0.05 \\
\hline
\end{tabular}

Tables 2 and 3 are the types of methyl ester compounds liberated from triglycerides after reacting with methanol, 
whereby the parameter I is pressure 15 bar, mixture volume 575 $\mathrm{mL}$, while parameter II is pressure $7 \mathrm{bar}$, mixture volume 550 $\mathrm{mL}$ for $1 \mathrm{~h}$ and temperatures $30-150{ }^{\circ} \mathrm{C}$. The parameter I was found that the Octanoic acid $\left(\mathrm{C}_{9} \mathrm{H}_{18} \mathrm{O}_{2}\right)$ appeared in the first time at 6.37 min with a composition of $12.17 \%$. Decanoic acid and Dodecanoic acid displayed at 12.45 and $17.89 \mathrm{~min}$ and yielded compositions 9.28 and $15.75 \%$. The most significant composition was Tetradecanoic acid $\left(\mathrm{C}_{15} \mathrm{H}_{30} \mathrm{O}_{2}\right)$ observed at $27.10 \%$ and followed by Hexadecanoic acid $\left(\mathrm{C}_{17} \mathrm{H}_{34} \mathrm{O}_{2}\right)$ [20]. Meanwhile, parameter II showed the light 1,2,3-Propanetrio $\left(\mathrm{C}_{3} \mathrm{H}_{8} \mathrm{O}_{3}\right)$ compound emerged firstly in $3.25 \mathrm{~min}$ but was at a small composition of $0.05 \%$.

Table 3 The coconut methyl ester (COME) and retention time (RT) using at the near isochoric subcritical esterification (V 550 $\mathrm{mL} ; \mathrm{P}_{\max }=7$ bar; $\mathrm{t}=1 \mathrm{~h} ; \mathrm{T}=30-150{ }^{\circ} \mathrm{C}$; ratio (in $\mathrm{V}$ ) coconut oil to methanol $=445.45: 104.83$; mass of $\mathrm{KOH}=4.5 \mathrm{~g}$

\begin{tabular}{|l|l|l|l|l|}
\hline $\begin{array}{l}\text { RT } \\
(\text { min })\end{array}$ & Compound & Formula & $\begin{array}{l}\text { Area } \\
(\%)\end{array}$ & $\begin{array}{l}\text { Height } \\
(\%)\end{array}$ \\
\hline 3.250 & $1,2,3$-Propanetrio & $\mathrm{C}_{3} \mathrm{H}_{8} \mathrm{O}_{3}$ & 0.05 & 0.07 \\
\hline 6.382 & Octanoic Acid & $\mathrm{C}_{9} \mathrm{H}_{18} \mathrm{O}_{2}$ & 11.96 & 12.11 \\
\hline 12.458 & Decanoic Acid & $\mathrm{C}_{11} \mathrm{H}_{22} \mathrm{O}_{2}$ & 9.50 & 11.29 \\
\hline 17.900 & Dodecanoic Acid & $\mathrm{C}_{13} \mathrm{H}_{26} \mathrm{O}_{2}$ & 20.70 & 27.98 \\
\hline 18.084 & - & - & 0.24 & 0.39 \\
\hline 18.786 & Dodecanoic Acid & $\mathrm{C}_{12} \mathrm{H}_{24} \mathrm{O}_{2}$ & 0.07 & 0.08 \\
\hline 20.291 & Heptadecanoic Acid & $\mathrm{C}_{18} \mathrm{H}_{36} \mathrm{O}_{2}$ & 0.02 & 0.03 \\
\hline 22.602 & Tetradecanoic Acid & $\mathrm{C}_{15} \mathrm{H}_{30} \mathrm{O}_{2}$ & 24.47 & 24.04 \\
\hline 29.128 & Hexadecanoic Acid & $\mathrm{C}_{17} \mathrm{H}_{34} \mathrm{O}_{2}$ & 14.88 & 9.10 \\
\hline 35.410 & $\begin{array}{l}\text { A,11-Octadecadienoic } \\
\mathrm{C}_{19} \mathrm{H}_{34} \mathrm{O}_{2}\end{array}$ & 2.19 & 1.54 \\
\hline 35.596 & 9-Octadecenoic Acid & $\mathrm{C}_{19} \mathrm{H}_{36} \mathrm{O}_{2}$ & 11.10 & 8.98 \\
\hline 35.750 & 9-Octadecenoic Acid & $\mathrm{C}_{19} \mathrm{H}_{36} \mathrm{O}_{2}$ & 0.01 & 0.03 \\
\hline 36.324 & Octadecanoic Acid & $\mathrm{C}_{19} \mathrm{H}_{38} \mathrm{O}_{2}$ & 4.57 & 4.17 \\
\hline 40.409 & Octadecanoic Acid & $\mathrm{C}_{21} \mathrm{H}_{40} \mathrm{O}_{2}$ & 0.12 & 0.08 \\
\hline 40.983 & Tetracosanoic Acid & $\mathrm{C}_{25} \mathrm{H}_{50} \mathrm{O}_{2}$ & 0.04 & 0.04 \\
\hline 48.448 & - & - & 0.06 & 0.06 \\
\hline
\end{tabular}

Octanoic acid (Octanoic acid) appeared clear at $6.38 \mathrm{~min}$, and the composition increased to $11.96 \%$. As time inclined to 12.46 and $17.90 \mathrm{~min}$, the compounds shown were Decanoic acid $\left(\mathrm{C}_{11} \mathrm{H}_{22} \mathrm{O}_{2}\right)$ and Dodecanoic acid $\left(\mathrm{C}_{13} \mathrm{H}_{26} \mathrm{O}_{2}\right)$ with composition 9.50 and $20.70 \%$, respectively. It was discovered that the Tetradecanoic acid $\left(\mathrm{C}_{15} \mathrm{H}_{30} \mathrm{O}_{2}\right)$ was the most significant composition obtained noted at $24.47 \%$, and RT was at 22.60 min. The RT and carbon chains increased the compositions were declining in which the point $(22.60 \mathrm{~min}, 24.04 \%)$ is the turning point. The composition of the Hexadecanoic acid $\left(\mathrm{C}_{17} \mathrm{H}_{34} \mathrm{O}_{2}\right)$, which displayed at $29.13 \mathrm{~min}$, was $14.88 \%$. The significant compositions that appeared on the spectra were 9Octadecenoic Acid $\left(\mathrm{C}_{19} \mathrm{H}_{36} \mathrm{O}_{2}\right)$ and Octadecanoic Acid
$\left(\mathrm{C}_{19} \mathrm{H}_{38} \mathrm{O}_{2}\right)$ that emerged at 35.60 and 36.32 min which was comparable with a specific methyl ester prepared from palm oil [21].

Even though the change of pressure did not influence quietly on the composition but from the two spectra showed that the pressure affected a variety of methyl esters compounds liberated. When the pressure was at 15 bar $(575 \mathrm{~mL})$, the COME was more diverse compared to that of 7 bar $(550 \mathrm{~mL})$. It was indicative that the more the pressure employed, the more COME compound formed, which would be investigated in the next work for pressure $>15$ bar.

\section{The Blending}

Before the blending, bioethanol was produced from a yeasted Arenga pinnata sap of which was distilled employing a reflux separator. The ethanol concentrations separated were ranged from $80-96 \%$ depending on the column temperature set. In the present work, bioethanol purity used was only from 94 $96 \%$, while $97 \%$ was obtained by employing lime absorption.

Table 4 Composition (\%v/v) of the pure ethanol, biodiesel, and water in an emulsion whereby COME was prepared in parameter I

\begin{tabular}{|c|c|c|c|c|c|c|c|}
\hline \multirow{2}{*}{$\begin{array}{c}\text { Et } \\
\text { \% }\end{array}$} & \multirow{3}{*}{ BD } & \multirow{2}{*}{ Et } & Wat & $\begin{array}{c}\text { Pure } \\
\text { Et }\end{array}$ & \multicolumn{4}{|c|}{$\begin{array}{c}\text { Composition } \\
(\%)\end{array}$} \\
\cline { 6 - 9 } & & & & & Pure Et & BD & Wat \\
\hline 97 & 13 & 7 & 0.21 & 6.79 & 33.95 & 65.00 & 1.05 \\
\hline 96 & 22 & 7 & 0.28 & 6.72 & 23.17 & 75.86 & 0.97 \\
\hline 95 & 30 & 7 & 0.35 & 6.65 & 17.97 & 81.08 & 0.95 \\
\hline 94 & 43 & 7 & 0.42 & 6.58 & 13.16 & 86.00 & 0.84 \\
\hline
\end{tabular}

Table 4 shows the compositions of the blended fuels of the pure ethanol, biodiesel, and water in stable emulsions for parameter I. The seven-milliliter aqueous ethanol were poured inside a $100 \mathrm{~mL}$ flask. The volume of absolute ethanol was $\%$ times the volume of aqueous ethanol, and the difference was the volume of water. For ethanol, $97 \%$ needed $13 \mathrm{~mL}$ biodiesel to become an emulsion solution in one phase in which composition was $33.95 \%$ pure ethanol, $65.00 \%$ biodiesel, and $1.05 \%$ water.

When ethanol concentration decreased to $96 \%$, the volume of biodiesel increased to $22 \mathrm{~mL}$ to they were mixed perfectly in stable emulsion with composition were $23.17 \%$ pure ethanol, $78.86 \%$ biodiesel, and $0.97 \%$ water. Though the ethanol concentration declined, the water content decreased since the biodiesel content was much higher. Especially, ethanol concentration 95 and $94 \%$, the emulsion started emerging droplets, but they were distributed throughout the mixture. It was found that the less ethanol concentration added was, the higher of biodiesel needed to form stable emulsions, and the range of pure ethanol, biodiesel, and water were 13.16-33.95\%, 
$65,00-86.00 \%$, and $0.84-1.05 \%$. Table 5 presents the composition of aqueous ethanol, diesel, and biodiesel in emulsion form for parameter I. The ratio of aqueous ethanol to diesel was altered 7:7, 7:10, 7:15, and 7:20. Firstly, aqueous ethanol and diesel were mixed inside a flask and were always separated into two phases.

Table 5 Compositions (\%v/v) of aqueous ethanol (Aq.Et.), diesel (D), and biodiesel (BD), in emulsion with volume ratio aqueous ethanol to diesel 7:7, 7:10, 7:15, and 7:20(parameter I)

\begin{tabular}{|c|c|c|c|c|c|c|}
\hline & \multicolumn{3}{|c|}{ Volume (mL) } & \multicolumn{3}{c|}{ Composition (\%) } \\
\cline { 5 - 7 } Et \\
\cline { 5 - 7 }
\end{tabular}

When biodiesel was presented in the mixture, the situation was changed dramatically. Two $7 \mathrm{~mL}$ of aqueous ethanol (96\%) and diesel could be entirely mixed with $18 \mathrm{~mL}$ biodiesel with composition was $21.88 \%$ Aq.Et., $21.88 \%$ D, and 56.25\% BD. The seven-milliliter aqueous ethanol and $10 \mathrm{~mL}$ diesel united with $25 \mathrm{~mL}$ biodiesel, and the composition changed to $16.67 \%$ Aq.Et., $23.81 \% \mathrm{D}$, and $59.52 \% \mathrm{BD}$. It was found that the more of diesel mixed with aqueous ethanol was, the more of biodiesel added to form stable emulsion as shown. When the volume of diesel increased to 15 and $20 \mathrm{~mL}$ mixed added into $7 \mathrm{~mL}$ aqueous ethanol, the biodiesel, which was added, was 38 and $50 \mathrm{~mL}$, respectively. The compositions of aqueous ethanol, diesel, and biodiesel were recorded at 11.67, 25.00, and $63.33 \% ; 9.09,25.97$, and $64.94 \%$.

With a similar volume of aqueous ethanol added to $7,10,15$, and $20 \mathrm{~mL}$ diesel, the biodiesel mixed was $32,38,45$, and 58 $\mathrm{mL}$. The combinations resulted the compositions of aqueous ethanol (95\%), diesel, and biodiesel containing droplets in emulsion were 15.22:15.22:69.57; 12.73:18.18:69.09; 101.45:22.39:67.16; and 8.23:23.53:68.24\%. Meanwhile, the compositions for aqueous ethanol $94 \%$ only resulted in two combinations as follows 11.67:11.67:76.67 and 7.45:10.64:81.91\%.

The fact found that the addition of biodiesel after stable emulsion was formed, did not occur a phase separation. In another study of the emulsion, aqueous ethanol and gasoline showed a different state. After the stable emulsion was attained, and then ethanol volume kept adding, the stable solution was not changed [22].

When ethanol concentration ethanol used was 95 , and $94 \%$, the appearance of the solution changed from clear- to droplets containing emulsions. The droplets were distributed uniformly throughout in emulsion, which was caused by the increase of water content. The phenomenon was an indication that the interface tension between molecules started to increase [23].

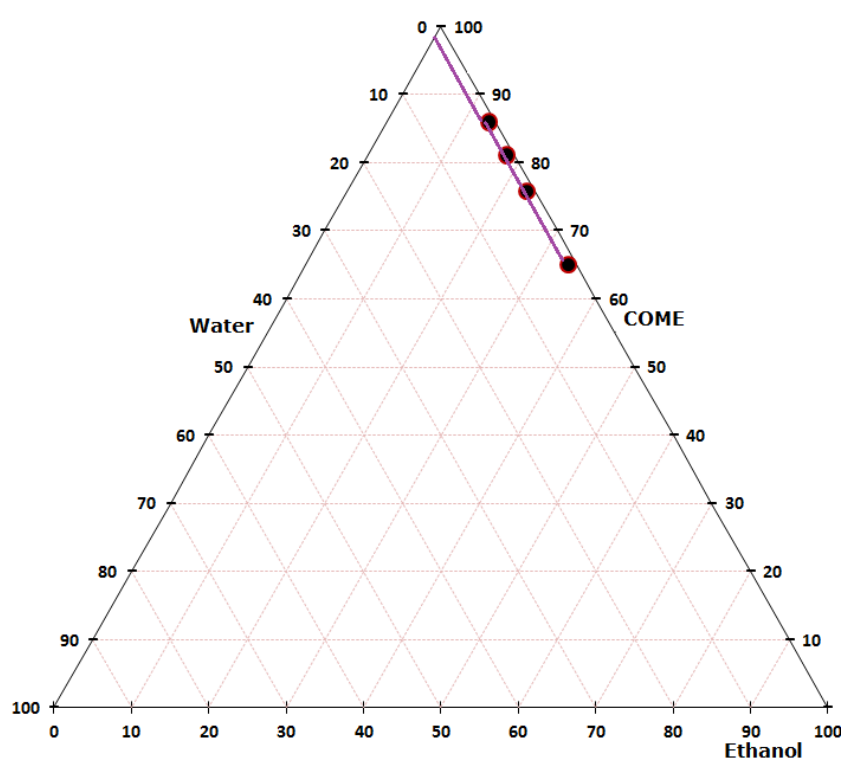

Figure 2 Triangular graph of the pure ethanol-biodiesel-water in an emulsion (parameter I)

\section{The triangular Analysis}

According to the observation that the emulsions formed consisted of two types, namely, stable- and unstable emulsion, or components were separated. The stable emulsions, however, were divided into two groups, such as the clear solution (ethanol > 96\%) and the substance appearing droplets (ethanol $<95 \%$ ). Meanwhile, components separated were grouped into unstable emulsion where the position depending on density each part and concentration of ethanol employed. It was discovered that after the stable emulsions were formed, and then the biodiesel keep being added continually, the components would not be separated. The biodiesel was dominant as functioning a surfactant because the $\left(\mathrm{C}=\mathrm{O}^{-}\right)$ester group on its chain could be interacting with positive poles $\left(\mathrm{H}^{+}\right)$ of water and ethanol. 


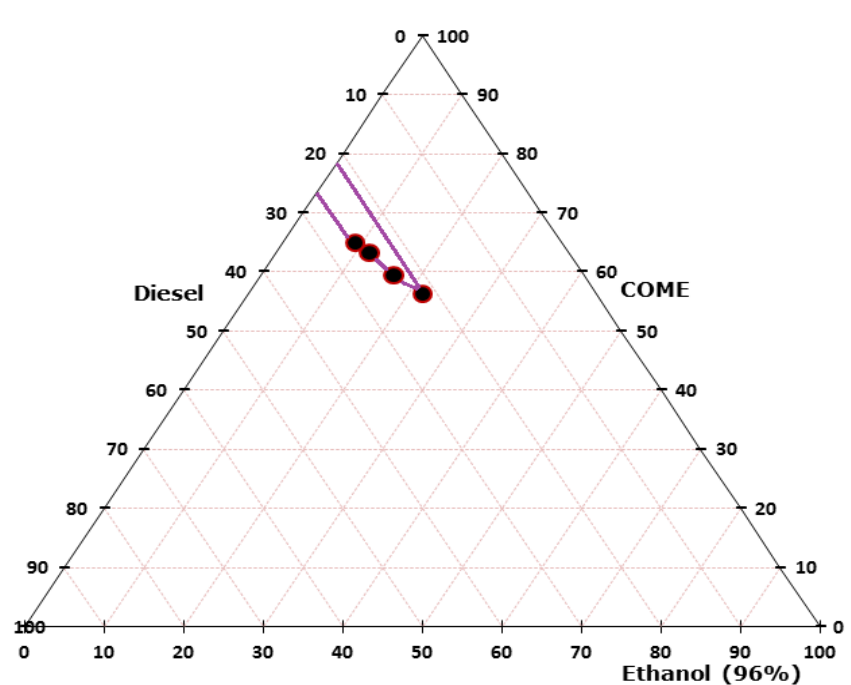

(A)

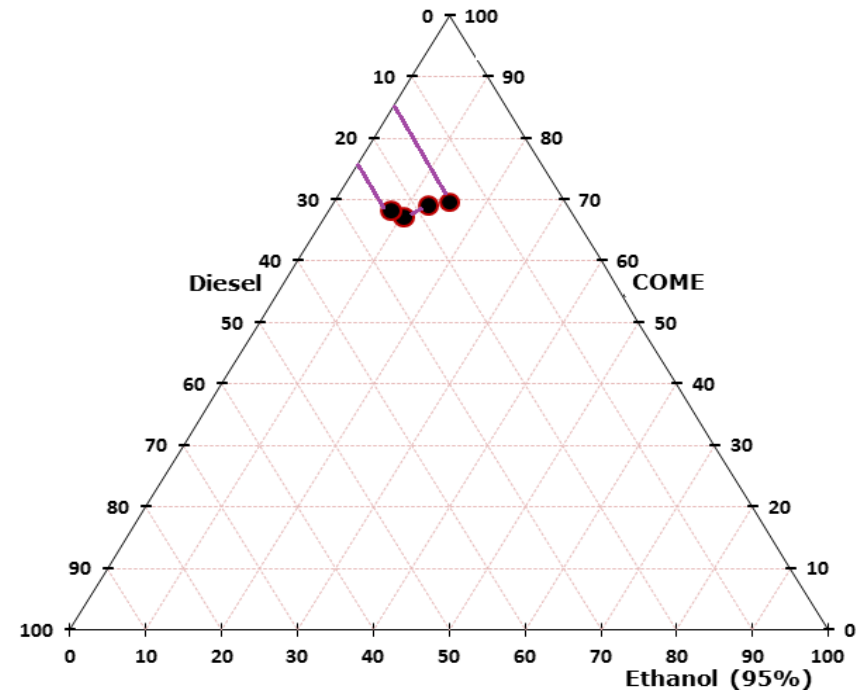

(B)

Figure 3. Triangular graph of the aqueous ethanol 96\%-diesel-biodiesel (A) and aqueous ethanol 95\%-diesel-biodiesel

(B) in an emulsion whereby COME was prepared using parameter I

When the composition met, the stable emulsions were formed. It means that there are two areas which are existed in the triangular graph, as shown in Fig 2, 3A, and 3B. The two areas where the substances are separated into two phases and one phase (stable emulsion). The blended fuel of pure ethanolbiodiesel-water in stable emulsion must be containing the least water to the area where the components were in the stable emulsion were very small located on the right equilibrium line (before reader) as presented in Figure 2. As previously described that the addition of COME continually after the stable emulsion was formed did not occur a separation. By adding the COME, keeping of composition of the water constant, and decreasing ethanol composition, the components were not separated. Even though the area where the substance is stable is small, the number of composition combinations between aqueous ethanol and COME is infinity.

The presence of diesel inside substance changed the trend of composition, including the area in the triangular graph, as displayed in Figure $3 \mathrm{~A}$ and 3B. The experiment conducted showed that the aqueous ethanol $(<97 \%)$ could not be entirely dissolved into diesel unless biodiesel in the exact composition exists.

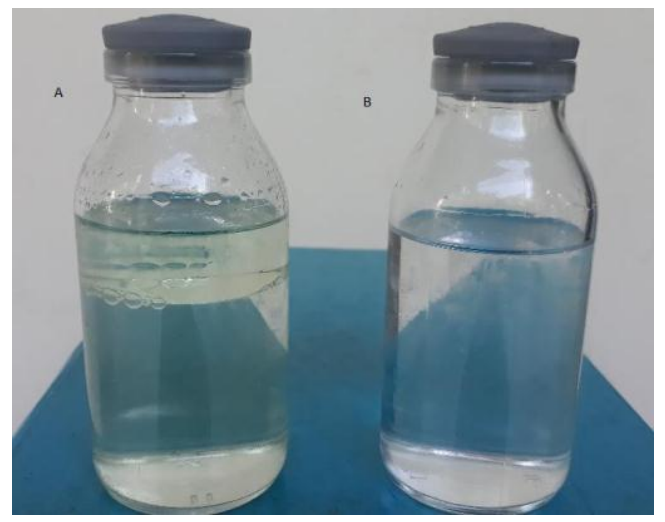

Figure 4 Photos of the unstable- (A) and stable emulsions (B)
The compositions of aqueous ethanol-diesel-biodiesel, as described in graphs, consisted of two kinds are those used ethanol 96 and $95 \%$. It was found that the increase of diesel or ethanol composition after the stable emulsion was formed, the separation has occurred. On the other hand, the rise of biodiesel composition would not tend to a separation. The area of stable emulsion located on the left of the triangular symmetry in which the shape is a trapezoidal look-like. Two straight lines that are parallel with the left side of triangular are representing the addition of biodiesel without changing the composition of diesel to the one phase keep constant. The appearance of the samples, which is unstable- and stable emulsion, are shown in Figure 4(A) and (B).

\section{Fuel Parameters}

Before applied to the engine, the fuel parameters of the blended fuels, such as density, API, SG, and cetane number, are measured and analyzed, as presented in Table 6. The parameters, density, SG, and API of the pure COME were 0.89, $0.89 \mathrm{~g} / \mathrm{cm}^{3}$, and 25.20; meanwhile, the cetane number was 86.40. The parameters of density and SG of the blended fuel the Aq.Et-BD conducted at 7 bar were similar at $0.85 \mathrm{~g} / \mathrm{cm}^{3}$, which were relatively comparable to previous work [24].

When diesel was employed with aqueous ethanol and biodiesel, which was prepared at 7 bar for $1 \mathrm{~h}$, all parameters could be detected and measured. The density, SG, and API were the same observed at $0.87 \mathrm{~g} / \mathrm{cm}^{3}$, while API and CN were 29.60 , 85 , respectively. When the pressure increase to 15 bar, the parameters density, and SG were similar at 0.87 , but the API and cetane numbers were changed to 29.80 and 74.40 that could be comparative as published [25]. 
Table 6 Fuel parameter data of the density, API, and CN of COME and their blends, Aq.Et-BD (7 bar), Aq.Et-D-BD (7 bar), Aq.Et-BD (15 bar), and Aq.Et-D-BD (15 bar;) employing ethanol concentration $96 \%$

\begin{tabular}{|c|c|c|c|c|}
\hline Sample & $\begin{array}{c}\rho \\
\left(\mathrm{g} / \mathrm{cm}^{3}\right)\end{array}$ & $\begin{array}{c}\mathrm{SG} \\
\left(15^{\circ} \mathrm{C}\right)\end{array}$ & $\begin{array}{c}\text { API } \\
\left(15^{\circ} \mathrm{C} /\right)\end{array}$ & $\mathrm{CN}$ \\
\hline COME & 0.89 & 0.89 & 25.20 & 86.40 \\
\hline $\begin{array}{c}\text { Aq.Et-BD } \\
(7 \text { bar })\end{array}$ & 0.85 & 0.85 & - & - \\
\hline $\begin{array}{c}\text { Aq.Et-D-BD } \\
(7 \text { bar })\end{array}$ & 0.87 & 0.87 & 29.60 & 85 \\
\hline $\begin{array}{c}\text { Aq.Et-BD } \\
(15 \text { bar })\end{array}$ & 0.84 & 0.84 & 34.80 & - \\
\hline $\begin{array}{c}\text { Aq.Et-D-BD } \\
(15 \text { bar })\end{array}$ & 0.87 & 0.87 & 29.80 & 75.40 \\
\hline
\end{tabular}

\section{API: American Petroleum Institute gravity.}

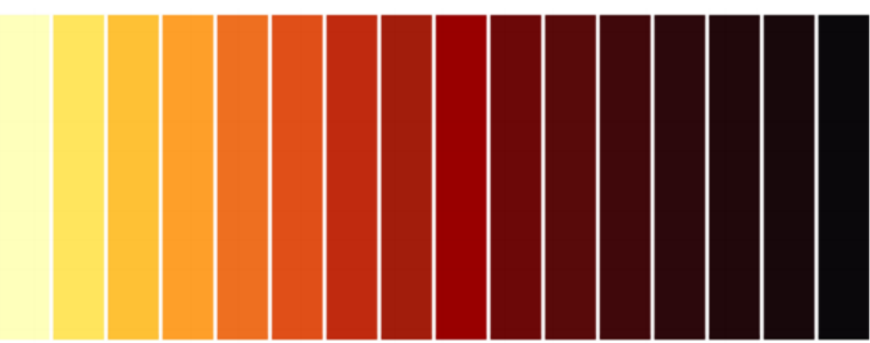

$\begin{array}{llllllllllllllll}0.5 & 1.0 & 1.5 & 2.0 & 2.5 & 3.0 & 3.5 & 4.0 & 4.5 & 5.0 & 5.5 & 6.0 & 6.5 & 7.0 & 7.5 & 8.0\end{array}$

Figure 5. The scale of the demonstrative light color of the flame appearing of the fuel-burning issued by ASTM D1500 standard

The other essential fuel parameters measured were viscosity, ASTM color, flash point, and pour point [26]. Two blended fuels that investigated were Aq.Et-BD and Aq.Et-D-BD using ethanol $96 \%$.

Table 7 Viscosity, ASTM Color, flash point and pour en of the blended fuels aqueous ethanol-biodiesel and aqueous ethanolbiodiesel-diesel using ethanol $96 \%$ (15 bar)

\begin{tabular}{|c|c|c|c|c|}
\hline Fuels & $\begin{array}{c}\text { Viscosity } \\
\mathbf{4 0}\end{array}$ & $\begin{array}{c}\text { ASTM } \\
\mathbf{~ \mathbf { ~ m } ^ { 2 }} \mathbf{~} \mathbf{s}\end{array}$ & $\begin{array}{c}\text { Flash } \\
\text { Color } \\
\text { Point }\left({ }^{\circ} \mathrm{C}\right)\end{array}$ & $\begin{array}{c}\text { Pour } \\
\text { Point, }{ }^{\circ} \mathrm{C}\end{array}$ \\
\hline $\begin{array}{c}\text { Aq.Et- } \\
\text { BD }\end{array}$ & 5.35 & D 1.5 & 70 & 0 \\
\hline $\begin{array}{c}\text { Aq.Et- } \\
\text { D-BD }\end{array}$ & 3.93 & D 0.5 & 53 & 5 \\
\hline
\end{tabular}

The viscosity, ASTM color, flash point and pour point of Aq.Et-BD was observed at $5.35 \mathrm{~mm}^{2} / \mathrm{s}$, D $1.50,70{ }^{\circ} \mathrm{C}$, and $0{ }^{\circ} \mathrm{C}$ as presented in Table 7. Based on the color standard issued by ASTM, as shown in Figure 5, the color was close to a yellowish, while the minimum point in which the fuel can be flown was similar to the melting point of the water at $0{ }^{\circ} \mathrm{C}$ when the diesel was added to the blends becoming (Aq.Et-D-BD, the parameter values were changed significantly.

The temperature in which the fuel vaporize enough for ignition dropped to $53{ }^{\circ} \mathrm{C}$, and the color was declined to D 0.5, which the yellow was more apparent. The thickness parameter of the fuel was dropping to $3.93 \mathrm{~mm}^{2} / \mathrm{s}$, but the pour point increased to $5^{\circ} \mathrm{C}$ that was close to reference published by authors [27-29].

Table 8 The amount of fuels (aqueous ethanol-biodiesel and aqueous ethanol-diesel-biodiesel) evaporated concerning temperature using ethanol 96\% (Sample 3b: Biodiesel-DieselAqueous ethanol; Sample 4a: Biodiesel-Aqueous ethanol)

\begin{tabular}{|c|c|c|}
\hline \multirow{2}{*}{ Testing } & \multicolumn{2}{|c|}{ Fuels } \\
\cline { 2 - 3 } & SAMPLE 3b & SAMPLE 4a \\
\hline IBP & 76 & 76 \\
\hline $5 \%$ & 76 & 77 \\
\hline $10 \%$ & 78 & 78 \\
\hline $20 \%$ & 237 & 78 \\
\hline $30 \%$ & 255 & 78 \\
\hline $40 \%$ & 270 & 81 \\
\hline $50 \%$ & 280 & 248 \\
\hline $60 \%$ & 290 & 266 \\
\hline $70 \%$ & 306 & 278 \\
\hline $80 \%$ & 330 & 303 \\
\hline $90 \%$ & 348 & 310 \\
\hline FBP & 353 & 330 \\
\hline Distillate, $\%$ & 98.50 & 98.50 \\
\hline Residu, ml & 0.3 & 0.3 \\
\hline
\end{tabular}

IBP: Initial boiling point

FBP: Final boiling point; 10\%: $10 \%$ of fuel evaporated

Table 8 shows the distillation property of two blended fuels, biodiesel-diesel-ethanol, and biodiesel-ethanol employing ethanol $96 \%$. The distillation property of the sample showed a similar trend whose temperatures increased abruptly at 78 and $81{ }^{\circ} \mathrm{C}$.

The ethanol part of the first fuel finished in advance and followed the second one. The final boiling point of the first fuel was at $353^{\circ} \mathrm{C}$ and the second was at $330^{\circ} \mathrm{C}$ which was relatively close to another study [30] The first sample contained a small fraction of diesel fuel in which the boiling point was higher than that of biodiesel.

\section{CONCLUSION}

Composition and specification of the blend fuels, aqueous ethanol-biodiesel, and aqueous ethanol-diesel-biodiesel from coconut oil, were successfully prepared and conducted. Aqueous ethanol 94-97\% could be blended with biodiesel and 
diesel in specific composition in the form of a stable emulsion. It was found that the composition of biodiesel in the stable emulsion was always larger than diesel or ethanol. The addition of biodiesel into solution after the equilibrium was attained would not be occurred a phase separation. The specification of fuel parameters, such as density, specific gravity, API, viscosity, flash point, cetane number, pour point, and distillation property, was measured and analyzed. The density of blended fuel, which was measured, was ranged from $0.84-$ $0.89 \mathrm{~g} / \mathrm{cm}^{3}$, which relatively similar to previous works. The quantity of viscosity was recorded at $3.93-5.35 \mathrm{~mm}^{2} / \mathrm{s}$, while ASTM-D6751 was standardized at $1.90-6.00 \mathrm{~mm}^{2} / \mathrm{s}$.

\section{ACKNOWLEDGMENTS}

The authors, thanks to The Ministry of The Higher Education Department of the Indonesian Government and Sam Ratulangi University in financial support of the work. We also give special gratitude to contributors to the following: Ronny Purwadi as the Head of Bioenergy Study Program, Chemical Engineering of ITB Bandung West Java; Silvya Y. Agnesty, Tun Sriana, and Zami Furqon, who chair the Laboratory of Oil and Gas Processing Engineering, Polytechnic of Energy and Minerals, Cepu Blora, Central Java; and Ramli Thahir the Head of Oil and Gas Laboratory, State Polytechnic of Samarinda, East Kalimantan. We thank you for their technical assistance in investigating the biodiesel property and fuel parameters.

\section{REFERENCES}

[1] Lockwood, M., 2015, “ Fossil Fuel Subsidy Reform, Rent Management and Political Fragmentation in Developing Countries," Journal New Political Economy, 20 (4), pp. 475-494.

[2] Nagy, K., and Körmendi, K., 2012, "Use of renewable energy sources in light of the New Energy Strategy for Europe 2011-2020”. Appl. Energy, 96, pp. 393-399.

[3] Omojola, O., Awogbemi, A., Inambao, F. L and Onuh, E. I. 2019, "Modelling and Optimization of Transesterification of Waste Sunflower Oil to Fatty Acid Methyl Ester: A case of Response Surface Methodology vs Taguchi Orthogonal Approach," Int. J. Eng. Res. Technol., 12 (12), pp. 2346-2361.

[4] Amin, N., Sabli, N., Izhar, S., and Yoshida, H., 2020, "Production of Valuable Materials from Sago Bark Using Subcritical Water Treatment," Int. J. Eng. Res. Technol., 13 (1), pp. 1-11.

[5] Azis, Z., Susanto, B. H., 2 and Nasikin, M., 2019, "Upgrading Gasoline Yield and Octane Quality in Fluid Catalytic Cracking by Coprocessing of Vacuum Gasoil with Palm Triglyceride Fatty Acid using REY-Type Zeolite Catalysts, Int. J. Eng. Res. Technol.,, 12 (12), pp. 2676-2682.

[6] Widjaja, A., Agnesty, S. Y., Sangian, H. F., and Gunawan, S., 2015, "Application of Ionic Liquid [Dmim]Dmp Pretreatment In the Hydrolysis of
Sugarcane Bagasse For Biofuel Production," Bull. Chem. React. Eng. Catal. 10(1), pp. 70-77.

[7] Belincanta, J., Alchorne, J. A., and Da Silva, M. T., 2016, "The Brazilian Experience with Ethanol Fuel: Aspects of Production, Use, Quality and Distribution Logistics,” Braz. J., Chem. Eng., 33, pp. 1091-1102.

[8] Tao, L., Tan, D. C. E., McCormick, R., Zhang, M., Aden, A., He, X., and Zigler, T. B., 2014, "TechnoEconomic Analysis And Life- Cycle Assessment Of Cellulosic Isobutanol and Comparison with Cellulosic Ethanol and N- Butanol," Biofuels, Bioprod. Bioref, 8(1), pp. 30-48.

[9] Harahap, F., Silveira, S., and Khatiwada, D., 2019, "Cost Competitiveness of Palm Oil Biodiesel Production in Indonesia,” Energy, 170, pp. 62-72.

[10] Ong, C. H., Mahlia, I. M. T., Masjuki, H. H., and Honnery, D., 2012, "Life Cycle Cost and Sensitivity Analysis of Palm Biodiesel Production," Fuel, 98, pp. 131-139.

[11] Khatiwada, D., Palmén, C., and Silveira, S., 2018, "Evaluating the Palm Oil Demand in Indonesia: Production Trends, Yields, and Emerging Issues," Biofuels, pp. 1-13.

[12] Lam, K. M., Tan, T. K., Lee, T. K., and Mohamed, R. A., 2009, "Malaysian Palm Oil: Surviving the Food Versus Fuel Dispute for A Sustainable Future," Renew. Sust. Energ., 13(6-7), pp. 1456-1464.

[13] Agarwal, A., Gupta, P., and Rajdeep, R., 2015, "Biodiesel Production for C.I. Engine from Various Non- Edible Oils: A Review," Int. J. Emerg. Eng. Res. Technol., 3 (1), pp. 8-16.

[14] Shahir, A. S., Masjuki, H. H., Kalam, A. M., Imran, A., and Ashraful, M. A., 2015, "Performance And Emission Assessment Of Diesel-BiodieselEthanol/Bioethanol Blend As A Fuel In Diesel Engines: A review," Renew. Sust. Energ., 48, pp. 62-78.

[15] Ribeiro, M. N., Pinto, C. A., Quintella, M. C., da Rocha, O. G., Leonardo, O., Teixeira, G. S., Guarieiro, N. L. L., Do, M., Rangel, C., Veloso, C. C. M., Rezende, C. J. M., da Cruz, S. R., de Oliveira, M. A., Torres, A. E., and de Andrade, B. J., 2007, "The Role of Additives for Diesel and Diesel Blended (Ethanol or Biodiesel) Fuels: A Review," Energ Fuel., 21, pp. 2433-2445.

[16] Yilmaz, N., 2012. Comparative Analysis of BiodieselEthanol-Diesel and Biodiesel-Methanol-Diesel Blends In A Diesel Engine. Energy, 40 (1), pp. 210-213.

[17] Benjumea, P., Agudelo, J., and Agudelo, A., 2008, "Basic Properties Of Palm Oil Biodiesel-Diesel Blends," Fuel, 87, pp. 2069-2075.

[18] Fernández-Feal, M.M.D.C., Sánchez-Fernández, L.R., and Sánchez-Fernández, B., 2017, "Distillation: Basic Test in Quality Control of Automotive Fuels, IntechOpen," Book Series, pp. 77-97. 
[19] Yin, J. Z., Xiao, M., Wang, A. Q., and Xiu, Z. L., 2008, "Synthesis of Biodiesel From Soybean Oil by Coupling Catalysis With Subcritical Methanol," Energy Convers. and Manag., 49(12), pp. 3512-3516.

[20] Karthickeyan, V., Balamurugan, P., and Senthil, R., 2019, "Environmental Effects of Thermal Barrier Coating with Waste Cooking Palm Oil Methyl Ester Blends in A Diesel Engine," Biofuels, 10(2), pp. 207220.

[21] Maulidiyah, M., Nurdin, F., Fatma, M., Natsir, D., and Wibowo, W., 2017, "Characterization of Methyl Ester Compound of Biodiesel From Industrial Liquid Waste of Crude Palm Oil Processing," Anal. Chem. Res., 12, pp. 1-9.

[22] Sangian, H. F., Tamuntuan, G. H., Mosey, H. I. R., Suoth , V., and Manialup, B H., 2017, "The Utilization of Arenga Pinnata Ethanol in Preparing One PhaseAqueous Gasohol," ARPN J. Eng. Appl. Sci., 12, pp. 7039-7046.

[23] Wang, F., Wu, J., Liu, Z., 2006, "Surface Tensions of Mixtures of Diesel Oil or Gasoline and Dimethoxymethane, Dimethyl Carbonate, or Ethanol," Energ Fuel., 20, pp. 2471-2474.

[24] Corral-Gómez, L., Rubio-Gómez, G., MartínezMartínez, S., and Sánchez-Cruz, A. F., 2019, "Effect of Diesel-Biodiesel-Ethanol Blends on The Spray Macroscopic Parameters in a Common-Rail Diesel Injection System.” Fuel, 241, pp. 876-883.

[25] Bezaire, N., Kapila Wadumesthrige, K.Y., Ng, S., and Salley, O. S., 2010, "Limitations of the Use of Cetane Index For Alternative Compression Ignition Engine Fuels", Fuel, 89, pp. 3807-3813.

[26] Lapuerta, M., Garcı'a-Contreras, R., Campos-Fernandez, J., and Dorado, P. M., 2010, "Stability, Lubricity, Viscosity, and Cold-Flow Properties of Alcohol-Diesel Blends," Energ Fuel., 24, pp. 4497-4502.

[27] Torres-Jimenez, E., SvoljšakJerman, M., Gregorc, A., Lisec, I., and Dorado, P.M., and Kegl, B., 2011, "Physical And Chemical Properties of Ethanol-Diesel Fuel Blends," Fuel, 90 (2), pp. 795-802.

[28] Mbarawa, M., 2010, "The Effect of Clove Oil And Diesel Fuel Blends on The Engine Performance And Exhaust Emissions of A Compression-Ignition Engine," Biomass Bioenerg., 34, pp. 1555-1561.

[29] Sarin, A., Arora, R., Singh, P. N., Sarin, R., Malhotra, K. R., and Kundu, K., 2009, "Effect of Blends of PalmJatropha-Pongamia Biodiesels on Cloud Point and Pour Point," Energy, 34, pp. 2016-2021.

[30] Alptekin, E., and Canakci, M., 2008, "Determination of the Density and the Viscosities of Biodiesel-Diesel Fuel Blends," Renew. Energy, 33, pp. 2623-2630. 